\title{
Mitigation of methane gas emission in rice by drip irrigation
}

\section{[version 1; peer review: 2 approved]}

\author{
Theivasigamani Parthasarathi (iD1, Koothan Vanitha², Sendass Mohandass², \\ Eli Vered $^{3}$ \\ ${ }^{1}$ VIT School of Agricultural Innovations and Advanced Learning (VAIAL), Vellore Institute of Technology, Vellore, Tamil Nadu, 632014, \\ India \\ 2Department of Crop Physiology, Tamil Nadu Agricultural University, Coimbatore, Tamil Nadu, 641003, India \\ ${ }^{3}$ Netafim Irrigation Ltd, Kibbutz Mahal, Israel
}

V1 First published: 28 Nov 2019, 8:2023

https://doi.org/10.12688/f1000research.20945.1

Latest published: 28 Nov 2019, 8:2023

https://doi.org/10.12688/f1000research.20945.1

\section{Abstract}

Background: Rice farming faces major challenges, including water limitation, drought and climate change in the current scenario of agriculture. Among the innovative water-saving techniques, drip irrigation is a forerunner, with maximized water-saving potential, increased grain yield and methane mitigation.

Methods: A field experiment was conducted comprising four different drip irrigation practices: (i) sub-surface drip irrigation (SDI) with 1.0 litre per hour (Iph) discharge rate emitters (DRE) (SDI+1.0 Iph DRE) (ii) SDI+0.6 Iph DRE, (iii) surface drip irrigation (DI) with 1.0 lph discharge rate emitters (DI+1.0 Iph DRE), (iv) DI+0.6 Iph DRE and were compared with $(v)$ a conventional flood aerobic irrigation (considered conventional).

Results: The estimated grain yield of rice was found to be $23.5 \%$, $20.3 \%$, and $15.1 \%$ higher under SDI+1.0 Iph DRE, SDI+0.6 Iph DRE and DI+1.0 Iph DRE practices, respectively, than the conventional method. A water saving of $23.3 \%$ was also observed for all drip practices compared with conventional practices. Seasonal methane emission flux declined $78.0 \%$ in the drip methods over the conventional irrigation: better mitigation than previously reported values (alternate wetting and drying (47.5\%) and system of rice intensification (29.0\%) practices). Continuous soil aeration and enhanced soil methanotrophs $(P<0.05)$ limit the peak methane emission in rice during the flowering phase in drip irrigation, which is reflected in the methane emission flux values. Consequently, the equivalent $\mathrm{CO}_{2}\left(\mathrm{CO}_{2}\right.$-eq) emissions and yield-scaled $\mathrm{CO}_{2}$ eq-emission were found to be significantly lower in SDI (43.8\% and $49.5 \%$, respectively), and DI $(25.1 \%$ and $26.7 \%$, respectively) methods as compared with the conventional that ensures better methane mitigation and future climate-smart rice production systems.

Conclusions: Drip irrigation could reduce the cumulative methane emission in aerobically grown rice. SDI + 1.0 Iph DRE practice can be

\section{Open Peer Review Approval Status \\ 1 2 \\ version 1 \\ 28 Nov 2019

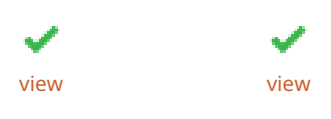 \\ 1. Prashantkumar S. Hanjagi ID, ICAR-Indian Agricultural Research Institute, New Delhi, India \\ 2. Gerard Arbat ID, University of Girona, Girona, Spain}

Any reports and responses or comments on the article can be found at the end of the article. 
applied in areas with inadequate water availability and effective in reducing the $\mathrm{CO}_{2}$-eq emission with better yield than conventional.

\section{Keywords}

Aerobic rice, Drip irrigation, Methane, CO2 eq-emission, Water

productivity

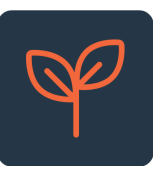

This article is included in the Agriculture, Food

and Nutrition gateway.

\section{Corresponding author: Theivasigamani Parthasarathi (tparthasarathicrp@gmail.com)}

Author roles: Parthasarathi T: Data Curation, Investigation, Methodology, Validation, Writing - Original Draft Preparation, Writing Review \& Editing; Vanitha K: Formal Analysis, Investigation, Methodology, Writing - Review \& Editing; Mohandass S: Conceptualization, Methodology, Resources, Supervision, Validation, Writing - Review \& Editing; Vered E: Funding Acquisition, Resources, Supervision, Validation

Competing interests: No competing interests were disclosed.

Grant information: The authors acknowledge Netafim Irrigation Ltd., Israel, for providing the funding.

The funders had no role in study design, data collection and analysis, decision to publish, or preparation of the manuscript.

Copyright: $\odot 2019$ Parthasarathi T et al. This is an open access article distributed under the terms of the Creative Commons Attribution License, which permits unrestricted use, distribution, and reproduction in any medium, provided the original work is properly cited.

How to cite this article: Parthasarathi T, Vanitha K, Mohandass $S$ and Vered E. Mitigation of methane gas emission in rice by drip irrigation [version 1; peer review: 2 approved] F1000Research 2019, 8:2023 https://doi.org/10.12688/f1000research.20945.1

First published: 28 Nov 2019, 8:2023 https://doi.org/10.12688/f1000research.20945.1 


\section{Introduction}

Agriculture was estimated to account for $10-20 \%$ of manmade

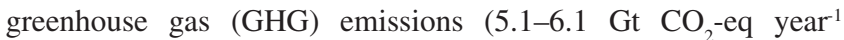
by 2030) worldwide (Smith et al., 2008; Tubiello et al., 2013). Rice fields are a major source of agricultural methane $\left(\mathrm{CH}_{4}\right)$ emissions (Malyan et al., 2016), contributing 20-40 Tg $\mathrm{CH}_{4}$ year ${ }^{-1}$ with a global emission of $52 \%$ (Sun et al., 2016). In India, rice cultivation covers about 44 million ha, the largest rice-producing area in Asia. To ensure food security for the exponential population, expanding the cropping area will increase methane emission. Therefore, reducing methane gas emission from the rice eco-system is the foremost preventive measure for a check-in global warming. Altering water level maintenance, an important parameter in measuring methane emission rate, by shifting water level from $15 \mathrm{~cm}$ to $10 \mathrm{~cm}$ could reduce $26.8 \%$ of total methane emissions in the rice field and supports a green eco-system (Sandin, 2005). So, effective water management practices, like midseason drainage, intermittent irrigation, system of rice intensification, alternate wetting and drying, direct dry seeding and aerobic rice cultivation, have the possible potential to mitigate methane emission for irrigated rice cultivation (Bronson et al., 1997; Feng et al., 2013; Trost et al., 2013). The system of rice intensification (SRI) practice reduces total methane emissions by $29.0 \%$ (Rajkishore et al., 2013), the value for alternate wetting and drying method was 44.0\% (Bouman et al., 2005; Bouman et al., 2007; Oo et al., 2018a; Oo et al., 2018b; Setyanto et al., 2018) and for aerobic rice practice was $51.0 \%$ (Joshi et al., 2009; Jain et al., 2014; Keppler et al., 2006; Sharma et al., 2016) compared with flooded rice cultivation. Although above-water management strategies show reduced methane emissions, consumption of more water for initial field setup and surface mode flood irrigation during an entire rice-growing cycle reduces the water productivity (Geethalakshmi et al., 2011) of the rice crop. By 2025, Asia's 130 million ha of irrigated rice area may experience physical and economic water scarcity (Tuong \& Bouman, 2003). In addition, India would need to produce up to 156 million tonnes of rice by 2030 (Dass et al., 2016) to feed its 1,523 million population. So, it is necessary to develop alternative irrigation strategies to mitigate methane emission as well as to improve the rice yield with limited water (Bouman et al., 2005; Reis et al., 2018; Yang \& Zhang, 2010).

The drip irrigation system for rice is a water-saving concept that allows the rice farmers to utilize water effectively through rootzone irrigation (Parthasarathi et al., 2018), which may lead to more rice crop seasons in a year. Also, drip irrigation has scope to mitigate methane emissions in the rice ecosystem. Drip irrigation to rice altered root traits (Parthasarathi et al., 2017), improved the water productivity (He et al., 2013; Parthasarathi et al., 2013; Parthasarathi et al., 2018) and nutrient use efficiency (Rajwade et al., 2018), and reduced pollution of the environment (Adekoya et al., 2014). Drip irrigation kept the field in the condition similar to aerobic/upland throughout the growing season (Adekoya et al., 2014). Rice ecosystems managed by drip irrigation have been scarcely reported with regards to methane emissions and mitigation potential. The effect of drip irrigation on soil environment, growth, yield and water productivity of rice remains unexplained.

We, therefore, hypothesized that the drip irrigation practice would allow for improved water saving, increased yield and the potential to mitigate methane release in the rice ecosystem. We tested this hypothesis and examined the drip irrigation practices (i.e. sub-surface drip irrigation, surface drip irrigation, 1.0 and $0.6 \mathrm{lph}$ discharge rate emitters) by conducting the field experiment in aerobic rice. We measured the methane emission, soil environment, rice growth, yield, water productivity, and microbial abundance. The results demonstrated that drip irrigation can be adapted to maintain more oxidative aerobic soil condition in rice crop.

\section{Methods}

Study background

The drip irrigation with methane emission experiment was conducted during summer season 2014 in the wetlands of Tamil Nadu Agricultural University, Coimbatore, Tamil Nadu, India (located at $110 \mathrm{~N}$ latitude, $770 \mathrm{E}$ longitude and at an altitude of $426.8 \mathrm{~m}$ above mean sea level). The prevailing agro-ecological conditions during the cultivation period were an average temperature of $34.2 / 23.3^{\circ} \mathrm{C} \quad(\mathrm{max} / \mathrm{min})$, sunshine hours of $7.3 \mathrm{hrs} \mathrm{day}^{-1}$ and total evaporation of $750.4 \mathrm{~mm}$ with total precipitation of $118.6 \mathrm{~mm}$ (Figure 1). Soil samples were collected in the field and soil physio-chemical properties were analysed and given in Table 1. Drip experiment was carried out using ADT (R) 45 rice variety (parentage: IR 50/ADT 37) that grows widely in the Cauvery delta zone of Tamil Nadu, India.

\section{Drip system}

The drip system was installed in the field with the help of Netafim Irrigation, Israel. The drip irrigation was supplied through $40 \mathrm{~mm}$ OD PVC pipes by $7.5 \mathrm{HP}$ motors from bore well and pressure maintained in the system was $1.2 \mathrm{~kg} \mathrm{~cm}^{-2}$. The drip treatments tested were sub-surface drip irrigation (SDI) with 1.0 litre per hour (lph) discharge rate emitters: i) SDI+1.0 lph DRE (SDI with $0.6 \mathrm{lph}$ discharge rate emitters); ii) SDI+0.6 lph DRE (surface drip irrigation (DI) with 1.0 lph discharge rate emitters); iii) DI+1.0 lph DRE (DI with $0.6 \mathrm{lph}$ discharge rate emitters) and iv) DI+0.6 lph DRE.

These were arranged in a randomized block design with three replications per method. Drip irrigation lateral pipes were laid out at a distance of $0.8 \mathrm{~m}$, emitters placed at $0.3 \mathrm{~m}$ distance for DI and SDI. Besides, the laterals placed at a depth of $15 \mathrm{~cm}$ below the soil surface for the SDI. Rice plants under drip irrigation system were irrigated at $125 \%$ pan evaporation (PE) using the Open Pan Evaporation (PE) values from a USWB Open Pan Evaporimeter. Scheduling of irrigation for the drip methods was conducted by working out effective rainfall using water balance method (Dastane, 1974). A conventional flood aerobic irrigation practice was considered the conventional method; these plots were kept unsaturated and the surface irrigated at $30-\mathrm{mm}$ depth when irrigation water/cumulative pan evaporation (IW/CPE) ratio reached 1.25. A graphical description of irrigation practices, crop evapotranspiration 


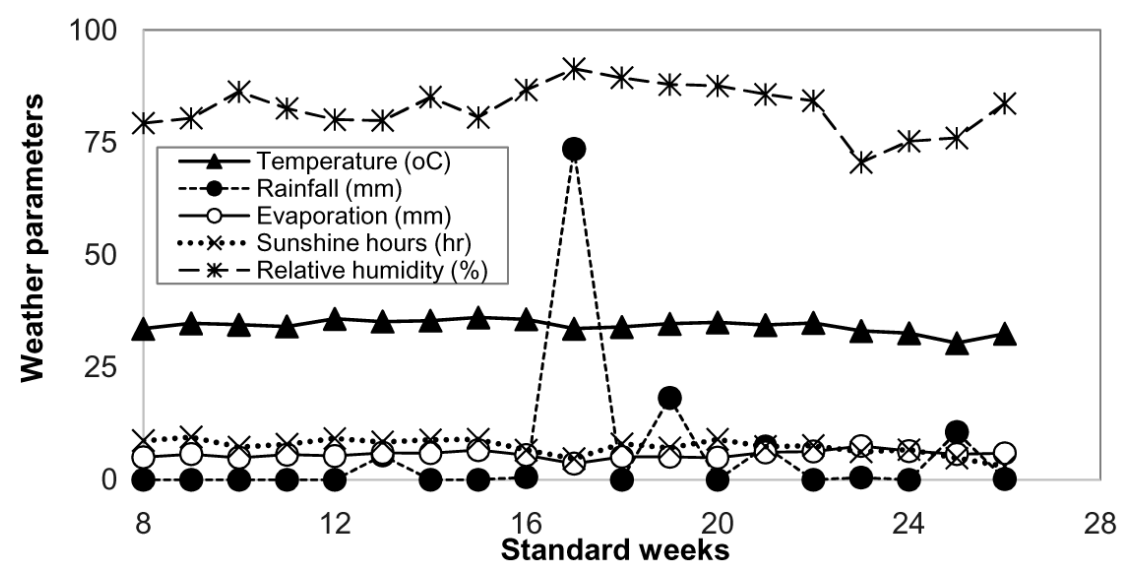

Figure 1. Weather condition [Air temperature $\left({ }^{\circ} \mathrm{C}\right)$, Rainfall $(\mathrm{mm})$, Evaporation $(\mathrm{mm})$, Sunshine hours $(\mathrm{hr})$ and relative humidity $(\%)$ ] prevailing during the cropping period.

Table 1. Soil physical and chemical properties of the experimental site.

\begin{tabular}{|c|c|c|c|c|c|}
\hline $\mathrm{pH}$ & $\begin{array}{c}\text { EC } \\
\left(\mathrm{dS} \mathrm{m}^{-1}\right)\end{array}$ & Organic carbon (\%) & $\begin{array}{c}\text { Available N } \\
\left(\mathrm{kg} \mathrm{ha}^{-1}\right)\end{array}$ & $\begin{array}{c}\text { Available P } \\
\left(\mathrm{kg} \mathrm{ha}^{-1}\right)\end{array}$ & $\begin{array}{c}\text { Available K } \\
\left(\mathrm{kg} \mathrm{ha}^{-1}\right)\end{array}$ \\
\hline 8.1 & 0.74 & 0.75 & 326 & 24.6 & 358 \\
\hline
\end{tabular}

(ET) and soil moisture prevailed during the experiment is given in the Extended data, Supplementary Figures 1 and 2 (Parthasarathi, 2019). Regarding crop management, recommended cultivation practices for aerobic rice were followed (TNAU Crop production guide, 2014). Application of preemergence herbicide, pendimethalin $30 \% \mathrm{EC}$ at $1.25 \mathrm{~kg}$ a.i. ha ${ }^{-1}$ at 3 days after sowing (DAS) and two-time hand weeding at 30 and 45 DAS have controlled the weeds. A recommended fertilizer dose of 150:50:50 kg ha-1 N:P:K was supplied as fertigation in the form of water-soluble fertilizers. Fertigation was applied through a venturi flume at weekly intervals. For the conventional irrigation method, the entire dose of $\mathrm{P}$ was applied basally before sowing. In the case of $\mathrm{N}$, the recommended dose was given at basal, tillering, booting and $50 \%$ flowering; $\mathrm{K}$ was given in two equal splits at basal and panicle initiation stages.

\section{Methane sampling and analysis}

The sampling of methane gas was performed using the closed chamber technique (Minamikawa et al., 2015). The chamber with rice plants is illustrated in Figure 2. The chamber was placed in between the laterals and $15 \mathrm{~cm}$ far from the emitters. Inside the chamber, an electric fan was installed to circulate the air. Samples were collected from 10:00 to 12:00 at 10, 30, 50, 70, 90 and 110 DAS. The gas samples were withdrawn from the top of the chamber using 50-ml gas-tight syringes at $0,10,20$ and $30 \mathrm{~min}$ after putting the chamber in its place. Air inside the chamber was thoroughly mixed by flushing the syringe five times before collection of the gas sample. The sample gases were transferred to $15 \mathrm{ml}$ vacuum glass vials with a rubber stopper and kept cool and dark until analysis.
The temporal increment of methane concentration inside the chamber was measured in terms of methane flux (Hutchinson \& Mosier, 1981). Collected gas samples were analysed using gas chromatography with flame ionization detector (FID). The following formula used to calculate methane gas emitted and concentration of gas denoted as $\mathrm{mg} \mathrm{m}^{-2} \mathrm{hr}^{-1}$ :

Total methane emissions $\left(\mathrm{mg} \mathrm{m}^{-2} \mathrm{hr}^{-1}\right)=[(\mathrm{Ps} \times \mathrm{Cs} / \mathrm{Pstd}) \times \mathrm{Vv} / \mathrm{Va}]$ $\times \operatorname{Vhx} \mathrm{A} \times \mathrm{H}$.

Where Ps = peak area for sample in gas chromatography; $\mathrm{Cs}=$ standard methane gas concentration $\left(\mathrm{mg} \mathrm{L}^{-1}\right) ; \mathrm{Vv}=$ vial volume $(\mathrm{ml}) ; \mathrm{Vh}=$ headspace volume of the chamber, i.e., [Chamber length*breadth*height] (ml); Va = air volume sampled $(\mathrm{ml}) ; \mathrm{A}=$ chamber area covered $\left(\mathrm{m}^{2}\right) ; \mathrm{H}$ : enclosure period (hr); Pstd : standard peak area in gas chromatograph. The equivalent $\mathrm{CO}_{2}\left(\mathrm{CO}_{2}\right.$-eq) emission for total methane was calculated using the following modified equation (Oo et al., 2018a): $\mathrm{CO}_{2}$-eq $=\left[\mathrm{TCH}_{4} \times 34\right]$, where $\mathrm{CO}_{2}$-eq is the total amount of equivalent $\mathrm{CO}_{2}$ emission $\left(\mathrm{kg} \mathrm{CO}_{2}\right.$-eq ha $\left.{ }^{-1}\right), \mathrm{TCH}_{4}$ is the total amount of methane emission $\left(\mathrm{kg} \mathrm{ha}^{-1}\right), 34$ is the global warming potentials for methane to $\mathrm{CO}_{2}$ over a 100-year time horizon (IPCC, 2013).

\section{Soil characteristics}

The soil physical measurements were recorded during methane gas collection. Soil redox potential (Eh) and $\mathrm{pH}$ were measured by portable Eh meter (EHS-120; Fujiwara Scientific Company Co., Ltd, Tokyo, Japan) with platinum-tipped electrodes and $\mathrm{pH}$ meter (Lutron model $\mathrm{pH}$ 212; Sunshine Instruments, India), respectively. Dissolved oxygen content $\left(\mathrm{mg} \mathrm{L}^{-1}\right)$ of 


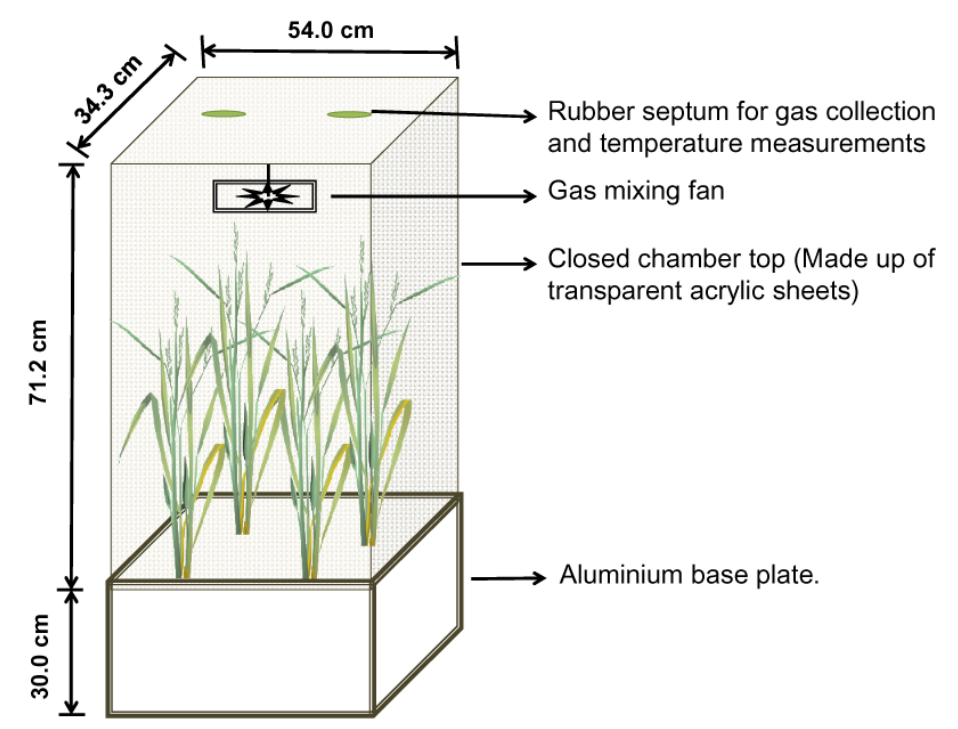

Figure 2. Diagram of closed diffusion chambers system used to collect methane emission in the rice field.

rice rhizosphere was measured with the analytical apparatus SJG-203A (Shanghai Leici Manufacturers, Shanghai, China). Enumeration of methanotrophic methane-oxidizing bacteria (MOB) was isolated and quantified during flowering phase based on the method of Graham et al. (1992). The soil samples were collected, diluted as suspension and analysed to $10^{-2}$ to $10^{-7}$ levels by $1-\mathrm{mL}$ suspension in tubes under ambient air condition.

\section{Plant characteristics}

The plant height $(\mathrm{cm})$ and total dry matter accumulation $\left(\mathrm{g} \mathrm{m}^{-2}\right)$ were measured during methane gas collection. The plant volume and root oxidizing power were taken from tagged plants during the flowering stage of rice. The total plant volume was calculated as the sum of root and shoot volume. Root and shoot volume was recorded by using the water displacement method (Bridgit \& Potty, 2002). The values were expressed in $\mathrm{cm}^{3}$ hill ${ }^{-1}$. The oxidizing power of roots was determined by the method of Ota (1970) and the activity expressed as $\mu \mathrm{g} \mathrm{g} \mathrm{g}^{-1} \mathrm{hr}^{-1}$. At the end of the experiment, replication wise harvesting was done for each treatment at the net plot $(2.4 \times 7.0 \mathrm{~m})$. The yield of rice was measured at $14 \%$ moisture level and yield expressed in $\mathrm{kg} \mathrm{ha}^{-1}$. Harvest index (HI) was calculated by using the formula of Yoshida et al. (1971) and expressed in percentage.

\section{Water use}

Water use was calculated by the sum of irrigation water applied $(\mathrm{mm})$ and the effective rainfall $(\mathrm{mm})$ during the cropping period (Dastane, 1974). Water productivity was calculated as the grain weight produced per unit of water input (Yang et al., 2005) and expressed as g grains $\mathrm{kg}^{-1}$ of water.

\section{Statistical analysis}

Randomized block design (RBD) analysis was carried out on various parameters (Water productivity, methane flux rate, cumulative methane, $\mathrm{CO}_{2}$-eq emissions, Yield-scaled $\mathrm{CO}_{2}$-eq emission, Grain yield, Straw yield, Harvest index, plant height, Total dry mass accumulation (TDMA), soil pH, soil Eh, Dissolved oxygen, plant volume, Root oxidizing power, Methanotrophs population) as per the procedure suggested by Gomez \& Gomez (1984). The coefficient of determination $\left(\mathrm{R}^{2}\right)$ was made between methanotrophs population and methane flux. Whenever the treatment differences were found significant, critical differences were worked out at 5\% probability level. Analysis of variance (ANOVA) was carried out for the recorded mean data using JMP, 2007 (SAS Institute, Cary, NC) software; appropriate standard errors of the means (SEM) and Fisher's Least Significant Difference at a significance of $\mathrm{P} \leq 0.05$ was calculated.

\section{Results and discussion}

The SDI and DI systems were installed in the field with $1.0 \mathrm{lph}$ and 0.6 lph DRE to the aerobic rice plants. The drip response results on methane gas emission, $\mathrm{CO}_{2}$-eq emission, soil $\mathrm{pH}$, soil redox potential, soil methanotrophs population from the rice ecosystem, plant height, total dry mass, yield, water productivity of rice were compared with the conventional flood aerobic irrigation practice; this section discusses the notable results. Data concerning methane emissions and weather for each group is available as Underlying data (Parthasarathi, 2019).

\section{Effect of drip irrigation on seasonal methane flux}

Seasonal methane flux pattern was observed to be similar in conventional and drip treatments (Figure 3c), and the flux increased gradually at the early rice-growing stage but declined at the end of the growth period (Figure 3c). A recent report by Oo et al. (2018a) on the alternate wetting and drying (AWD) water-saving method in rice emitted methane gas with two peak emissions during the vegetative phase. Contrarily, drip and conventional aerobic irrigation practices had a single emission peak during the flowering phase (70 DAS), 


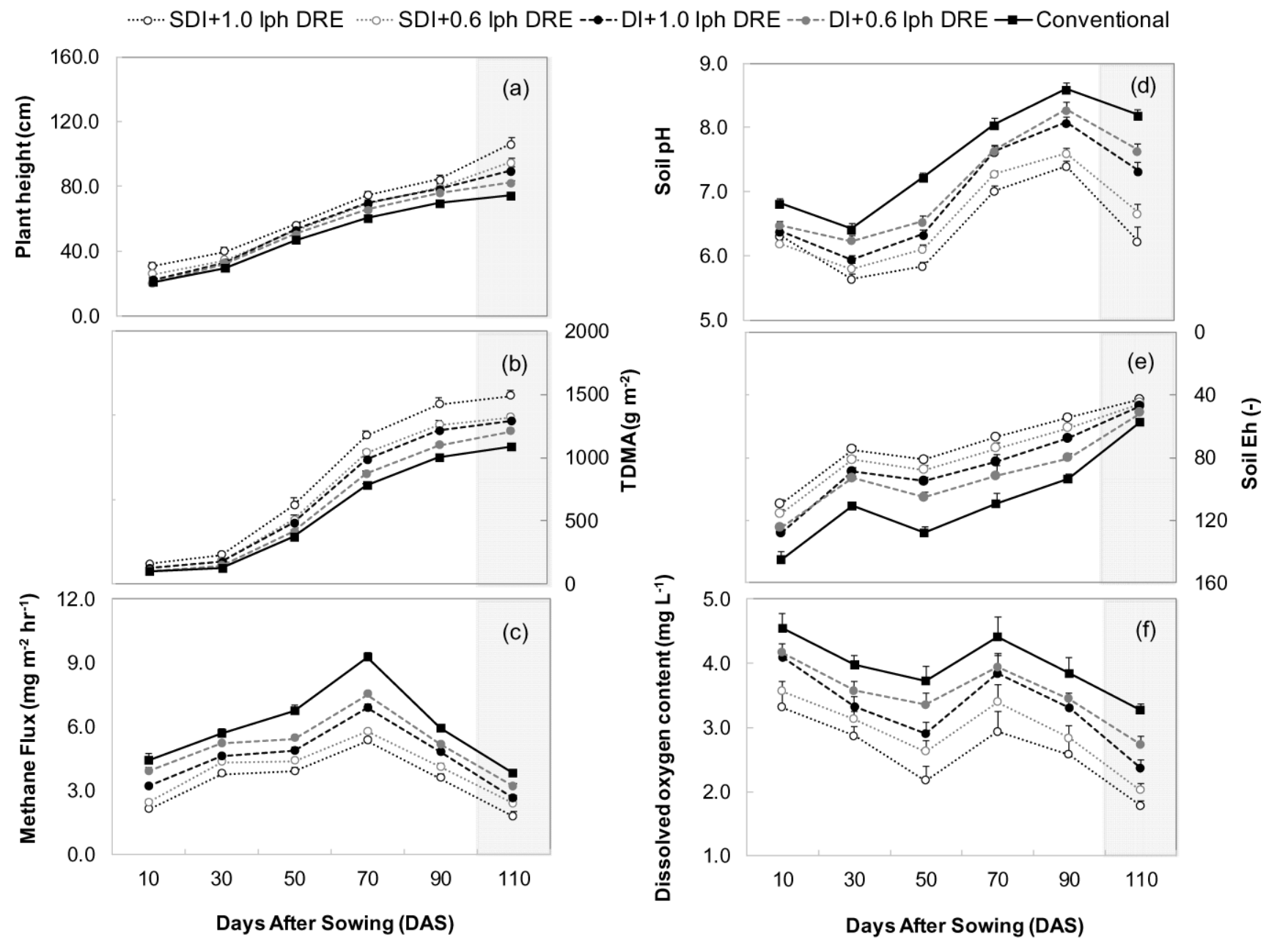

Figure 3. Effect of drip treatments on rice growth, change in methane flux, soil pH, soil Eh (redox potential) and dissolved oxygen content of drip-irrigated soil environment. Error bars indicate standard error of the mean $(n=6)$. Shading indicates the period after post-flowering phase (100 DAS). SDI, sub-surface drip irrigation; DI, surface drip irrigation; DRE, discharge rate emitters; Conventional, conventional flood aerobic irrigation.

particularly at 10 days before and after anthesis. This is because the aerobic condition lacked the dominant pathway of direct methane emission by lesser aerenchyma pore spaces in the root (see Extended data, Supplementary Information 2 (Parthasarathi, 2019)). This is the reason for the reduced methane transport through rice shoots from soil to the atmosphere and was well explained by Bhattacharyya et al. (2019) in rice. Contrary to the sharp decline in methane flux at harvest phase in flooded paddy (Minamikawa et al., 2015), drip and conventional aerobic irrigated rice showed a gradual and slow decline influx after 100 DAS (shaded area in Figure 3). The decrease in methane transport capacity of rice plants under an aerobic environment is the possible explanation for methane reduction after flowering (Figure 3c) and the response was reverse for flooded paddies (Minamikawa et al., 2015). These different responses to irrigation conditions between flooded and aerobic environment explain the significance of the drip system on methane mitigation potential (Table 2).
The SDI at 1.0 and $0.6 \mathrm{lph}$ DRE practices found a significant reduction in methane emission during vegetative to postflowering phases due to discontinuous soil aeration near the root zone and lack of carbon substrate for methane production (root exudates) during the growing season. Similar reduction reported in the midseason drained paddy field (Jiao et al., 2006) and these were in agreement with Yan et al. (2005) and Sander et al. (2015), who reported an average methane reduction of $40-60 \%$ by multiple soil aerations.

As hypothesized, a significant reduction $(\mathrm{P}<0.05)$ in the rate and cumulative methane flux was observed under drip irrigation methods over the conventional. Lesser methane flux rate (Table 2), cumulative methane (Table 3) emitted in SDI + $1.0 \mathrm{lph}$ DRE (3.37 mg m$~ m^{-2} \mathrm{~h}^{-1}$ and $97.2 \mathrm{~kg} \mathrm{ha}^{-1}$, respectively) treatment with greater mean significance over DI +1.0 lph DRE (4.50 $\mathrm{mg} \mathrm{m}^{-2} \mathrm{~h}^{-1}$ and $129.6 \mathrm{~kg} \mathrm{ha}^{-1}$, respectively) and conventional (6.00 $\mathrm{mg} \mathrm{m}^{-2} \mathrm{~h}^{-1}$ and $172.9 \mathrm{~kg} \mathrm{ha}^{-1}$, respectively). 
Table 2. Water usage, water productivity and methane flux $\left(\mathrm{mg} \mathrm{m}^{-2} \mathrm{~h}^{-1}\right)$ by different drip irrigation treatments and conventional aerobic rice growing seasons. Numbers in the table represent means \pm standard deviation $(n=3)$. Letters indicate significant differences $(P<0.05)$ among means according to an ANOVA.

\begin{tabular}{|c|c|c|c|c|c|}
\hline Treatments & $\begin{array}{l}\text { Total water } \\
\text { applied }(\mathrm{mm})\end{array}$ & $\begin{array}{l}\text { Irrigation } \\
\text { water }(\mathrm{mm})\end{array}$ & $\begin{array}{l}\text { Effective rainfall } \\
\qquad(\mathrm{mm})\end{array}$ & $\begin{array}{l}\text { Water productivity } \\
\text { (g grains } \mathbf{~ k g}^{-1} \text { of } \\
\text { water) }\end{array}$ & $\begin{array}{c}\text { Methane flux } \\
\text { rate } \\
\left(\mathrm{mg} \mathrm{m}^{-2} \mathrm{~h}^{-1}\right)\end{array}$ \\
\hline SDI+1.0 Iph DRE & 591.1 & 509.7 & 81.5 & $0.82 \pm 0.03^{A}$ & $3.37 \pm 0.2^{D}$ \\
\hline SDI+0.6 Iph DRE & 591.1 & 509.7 & 81.5 & $0.77 \pm 0.04^{\mathrm{AB}}$ & $3.87 \pm 0.2^{\mathrm{CD}}$ \\
\hline DI+1.0 Iph DRE & 591.1 & 509.7 & 81.5 & $0.72 \pm 0.02^{B}$ & $4.50 \pm 0.2^{\mathrm{BC}}$ \\
\hline DI+0.6 Iph DRE & 591.1 & 509.7 & 81.5 & $0.70 \pm 0.02^{B}$ & $4.98 \pm 0.2^{B}$ \\
\hline Conventional & 771.5 & 690.0 & 81.5 & $0.54 \pm 0.02^{c}$ & $6.00 \pm 0.3^{A}$ \\
\hline
\end{tabular}

SDI, sub-surface drip irrigation; DI, surface drip irrigation; DRE, discharge rate emitters; Conventional, conventional flood aerobic irrigation.

Table 3. Effect of drip system on cumulative methane, $\mathrm{CO}_{2}$-eq emission, yield-scaled $\mathrm{CO}_{2}$-eq emission, and rice yield. Numbers in the table represent means \pm standard deviation $(n=3)$. Letters indicate significant differences $(P<0.05)$ among means according to an ANOVA.

\begin{tabular}{|c|c|c|c|c|c|c|}
\hline \multirow[t]{2}{*}{ Treatments } & \multirow{2}{*}{$\begin{array}{l}\text { Cumulative } \\
\text { methane } \\
\left(\mathrm{kg} \mathrm{ha}^{-1}\right)\end{array}$} & \multirow{2}{*}{$\begin{array}{l}\mathrm{CO}_{2} \text {-eq emissions } \\
\left(\mathrm{kg} \mathrm{CO} \mathrm{ha}^{-1}\right)\end{array}$} & \multirow{2}{*}{$\begin{array}{c}\text { Yield-scaled } \\
\mathrm{CO}_{2} \text {-eq } \\
\text { emission } \\
\left(\mathrm{kg} \mathrm{CO}_{2} \text {-eq t } \mathrm{t}^{-1}\right)\end{array}$} & \multicolumn{3}{|c|}{ Yield Observation } \\
\hline & & & & $\begin{array}{c}\text { GY } \\
\left(\mathrm{Kg} \mathrm{ha}^{-1}\right)\end{array}$ & $\begin{array}{c}\text { SY } \\
\left(\mathrm{Kg} \mathrm{ha}^{-1}\right)\end{array}$ & $\begin{array}{c}\text { HI } \\
(\%)\end{array}$ \\
\hline SDI+1.0 Iph DRE & $97.2 \pm 6.0^{\mathrm{D}}$ & $3304.8 \pm 202.5^{\mathrm{D}}$ & $300.1 \pm 18.4^{c}$ & $4489 \pm 111.9^{A}$ & $7297 \pm 243.3^{A}$ & $38.1 \pm 0.31^{\mathrm{A}}$ \\
\hline SDI+0.6 Iph DRE & $111.4 \pm 5.9 \mathrm{CD}$ & $3788.9 \pm 200.7^{C D}$ & $348.1 \pm 18.4^{C}$ & $4305 \pm 69.0^{A}$ & $7234 \pm 250.5^{\mathrm{AB}}$ & $37.4 \pm 0.60^{\mathrm{AB}}$ \\
\hline DI+1.0 Iph DRE & $129.6 \pm 6.8^{\mathrm{BC}}$ & $4406.4 \pm 231.6^{\mathrm{BC}}$ & $435.6 \pm 22.8^{B}$ & $4038 \pm 125.6^{\mathrm{B}}$ & $6943 \pm 304.3^{\mathrm{AB}}$ & $36.8 \pm 0.70^{\mathrm{AB}}$ \\
\hline DI+0.6 Iph DRE & $143.5 \pm 6.7^{B}$ & $4877.8 \pm 230.9^{\mathrm{B}}$ & $499.5 \pm 23.8^{B}$ & $3783 \pm 60.0^{\mathrm{B}}$ & $6719 \pm 295.7^{\text {АВ }}$ & $36.1 \pm 0.75^{\mathrm{BC}}$ \\
\hline Conventional & $172.9 \pm 8.9^{A}$ & $5879.7 \pm 303.0^{A}$ & $594.2 \pm 30.6^{A}$ & $3430 \pm 65.2^{c}$ & $6562 \pm 110.3^{B}$ & $34.3 \pm 0.66^{c}$ \\
\hline Mean & 130.9 & 4451.5 & 435.5 & 4009.2 & 6950.9 & 36.6 \\
\hline
\end{tabular}

SDI, sub-surface drip irrigation; DI, surface drip irrigation; DRE, discharge rate emitters; Conventional, conventional flood aerobic irrigation.

The drip treatments (SDI+1.0 lph DRE, SDI+0.6 lph DRE, DI+1.0 lph DRE, DI+0.6 lph DRE) might have directed to more oxygen penetration to the root zone that inhibits the methanogenic bacteria by methane oxidation. However, the dissolved oxygen content declined significantly in drip practice over the conventional methods; we discuss the reason for the lower values in the up-coming section. Soil methanotrophic bacteria oxidizing methane gas using molecular oxygen in drained paddy soil (Jiao et al., 2006) was the reason for the above reduction in methane flux rate, cumulative methane flux under drip environment. This response was further confirmed an increased in methanotroph population of $39.8 \%$ in SDI+1.0 lph DRE, $32.2 \%$ in SDI+0.6 lph DRE $\left(44.7 \times 10^{5}\right.$ cells $\left.\mathrm{g}^{-1}\right)$ followed by $24.8 \%$ in DI+1.0 lph DRE over the aerobic zones of the rhizosphere (Figure 4). The regression line (Figure 5) represents a negative slope $\left(y=-0.1097 x+11.407, R^{2}=46.1\right)$ or the relationship between methanotrophs population and methane emission that indicates the drip practice reduces the methane by increased methanotrophs. Similarly, drip practices inhabited the aerobic interfaces of the methanogenic environment, that inhibit methanogenesis by killing the methanogenic bacteria
(Hanson \& Hanson, 1996) and these processes were influenced by the soil physio-chemical properties, and plant growth parameters (Luo et al., 2013).

\section{Effect of drip irrigation on rice growth and surrounding environment}

The drip irrigation practices had a considerable change in rice growth in terms of plant height $(29.4 \%)$ and total dry mass accumulation (TDMA) (26.9\%) than conventional systems. These were significantly increased under SDI and DI methods, irrespective of emitter discharge rates, over the conventional method. These results were consistent with the findings of previous studies, which found that the drip irrigation had improved the production potential of rice under non-flooded irrigation (He et al., 2013 and Parthasarathi et al., 2015). The total dry mass of rice did not differ significantly between drip irrigation and conventional irrigation up to 30 DAS, although after anthesis (70 DAS), it significantly improved under SDI $+1.0 \mathrm{lph}$ DRE practice (Figure 3a). This was mainly related to enhanced dry mass accumulation after anthesis, which explained by Parthasarathi et al. (2015) and Parthasarathi et al. (2018), who 

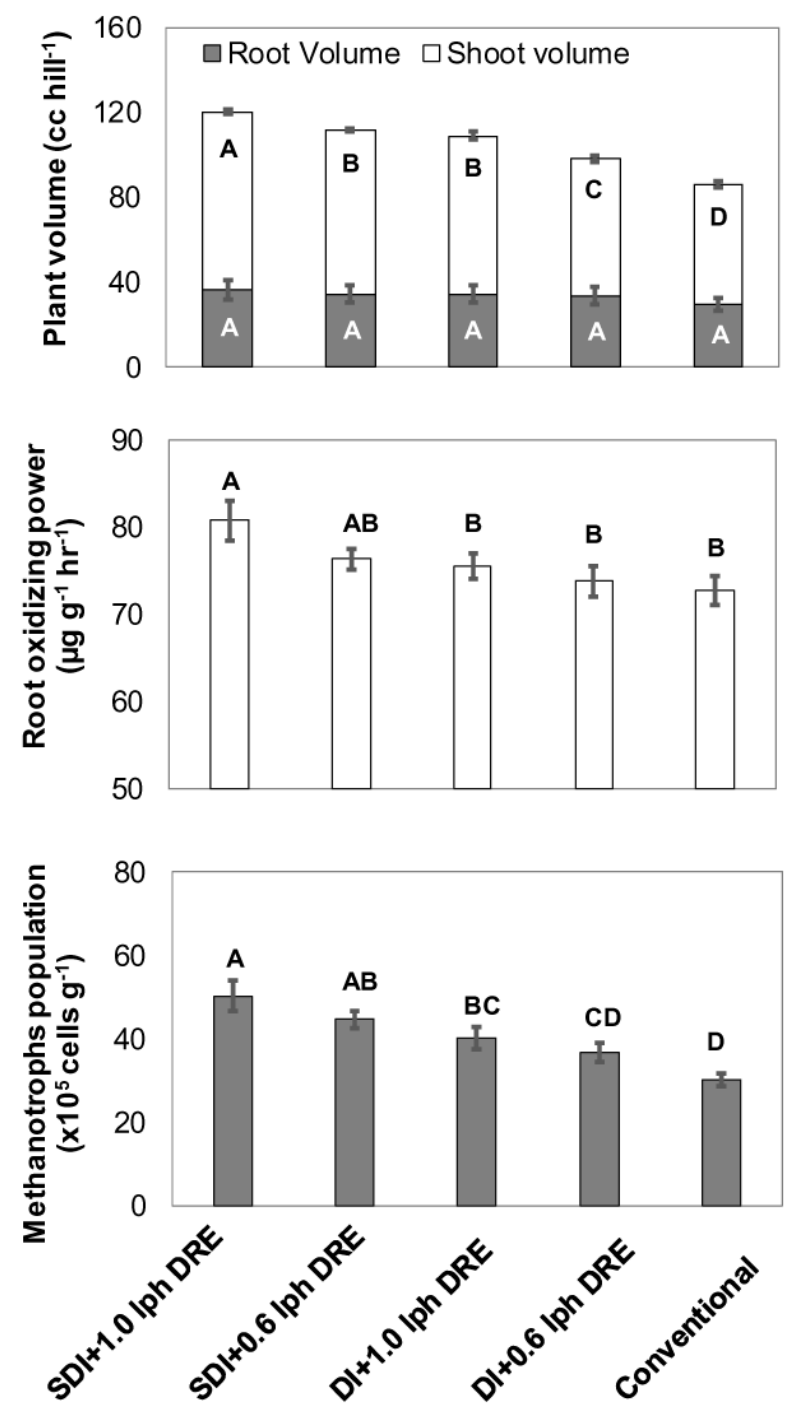

Figure 4. Effect of drip irrigation treatments on change in plant volume (root+shoot), root oxidizing power and soil methanotrophs population. Error bars indicate standard error of the mean $(n=6)$. Different letters denote significant differences among means derived using an ANOVA and student test. SDI, sub-surface drip irrigation; DI, surface drip irrigation; DRE, discharge rate emitters; Conventional, conventional flood aerobic irrigation.

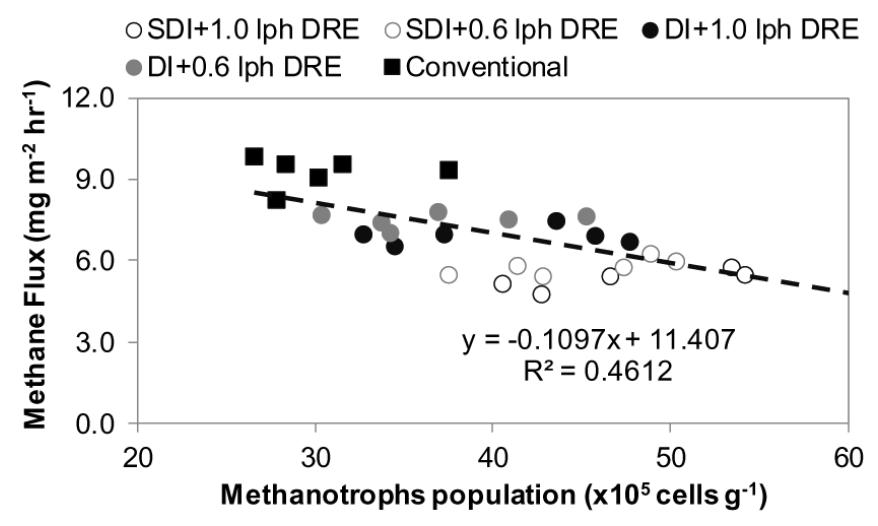

Figure 5. Methane emission as a function of methanotroph population under drip and conventional treatments during flowering. The black line shows a regression line $(y=-0.1097 x+11.407)$. The $r^{2}$ is the coefficient of determination. SDI, sub-surface drip irrigation; DI, surface drip irrigation; DRE, discharge rate emitters; Conventional, conventional flood aerobic irrigation. 
reported drip irrigation increased the plant height and leaf photosynthetic rates of rice during post-anthesis. TDMA showed a moderate change during the early growth and vegetative phase of rice under SDI and DI methods (Figure 3b), which reasoned for the lesser emission of methane over conventional. These results corroborated with the findings of Arafa et al. (2009) in wheat under SDI system.

Higher dry mass and lower root volume of rice facilitated oxygen transport into the rhizosphere, stimulating methane oxidation (Ma et al., 2010). Similarly, Figure 4 illustrates unaffected root zone volume and increased shoot volume under drip irrigation favours methane oxidation in comparison with the conventional method. This might be due to the favourable balance between root and shoot translocation of assimilates, nutrients and water (Kludze et al., 1993). Higher shoot volume increased the contact surface between roots that enhanced the methane oxidation rates under drip irrigated rice environment and were in agreement with methane oxidation studies in rice by Zhao et al. (2013). SDI + $1.0 \mathrm{lph}$ DRE treatment significantly improved the root oxidase activity $\left(80.7 \mu \mathrm{g} \mathrm{g}^{-1} \mathrm{hr}^{-1}\right)$ than the conventional $\left(72.7 \mu \mathrm{g} \mathrm{g}^{-1} \mathrm{hr}^{-1}\right.$ ) (Figure 4). This indicated an overall higher oxidation status and might have accelerated methane oxidation in the root rhizosphere, which eventually reduced the methane gas emission (Kong et al., 2009).

Among the irrigation treatments, drip-irrigated rice had higher $(\mathrm{P}<0.05)$ soil Eh than conventional. Superior Eh levels reasoned for the lesser emission $(\mathrm{P}<0.05)$ of methane under SDI+1.0 lph DRE drip practice (Figure 3e). Present results followed the study of Oo et al. (2018a), who reported water management practice improved the soil redox potential in flooded rice. Dorau \& Mansfeldt (2015) and Minamikawa et al. (2015) reported that higher Eh was resulted by the low $\mathrm{pH}$ in soil solution and the similar was observed in SDI+1.0 lph DRE followed by SDI+0.6 lph DRE and DI+1.0 lph DRE practices (Figure 3d). This acidic shift might also be due to the supply of water-soluble fertilizers by drip fertigation. This low soil $\mathrm{pH}$ could be the reason for the altered balance between $\mathrm{CH}_{4}$ and $\mathrm{CO}_{2}$ under drip irrigation by soil organic matter decomposition (Kongchum, 2005). Thus, low soil $\mathrm{pH}$ had a considerable effect, but this was alongside soil oxygen properties, which are likely to be responsible for reduced methane emissions (Kajiura et al., 2018). SDI + $1.0 \mathrm{lph}$ DRE treatment registered lesser $(\mathrm{P}<0.05)$ dissolved oxygen (DO) in soil than the conventional during all the phenophases (Figure 3f). This condition led to an increase in the soil oxygen concentration that leads to inhibition of soil organic matter oxidation which directly and indirectly, inhibited the methanogenesis (Kato et al., 2012; Zhou et al., 2014). Soil organic carbon (SOC) of oxygen-enhanced soil was oxidized into carbon dioxide $\left(\mathrm{CO}_{2}\right)$ instead of methane $\left(\mathrm{CH}_{4}\right)$, which ultimately reduced the root zone methane formation (Sun et al., 2016). This contrasted with flooded rice (Sharkawi et al., 2009), where increased DO reduces the methane emission but DO in the rhizosphere was controlled by irrigation water quantity.
Effect of drip irrigation on water usage, crop productivity, and $\mathrm{CO}_{2}$-eq emission

Under drip irrigation, the total water saving compared with conventional flood aerobic irrigation was $23.3 \%$ (Table 2). The maximum saving of irrigation water with aerobic irrigation was 50\% (Peng et al., 2006), with alternate wetting and drying was 47\% (Oo et al., 2018a) and with the system of rice intensification was only $27.4 \%$ (Suryavanshi et al., 2013), relative to flooded rice. Higher water savings under drip irrigation over the conventional method was due to the supply of irrigation water being based on the evapotranspiration demand for rice. The water productivity of $0.82 \mathrm{~g}_{\text {grains }} \mathrm{kg}^{-1}$ of water obtained under drip irrigation (SDI + 1.0 lph DRE) due to higher yield potential and substantially higher water productivity than the previous reports (Bouman et al., 2006; Kato et al., 2009).

Drip irrigation improves the grain yield of rice by $9.3-23.6 \%$ over the conventional flood aerobic irrigation. Higher grain yield (4489 $\left.\mathrm{kg} \mathrm{ha}^{-1}\right)$, straw yield $\left(7297 \mathrm{~kg} \mathrm{ha}^{-1}\right)$ and harvest index $(38.1 \%)$ were obtained under SDI + $1.0 \mathrm{lph}$ DRE practice, and it was significantly lower using the conventional method (3430 kg ha-1, $6562 \mathrm{~kg} \mathrm{ha}^{-1}$ and $34.3 \%$, respectively) (Table 3). The yield of rice was significantly superior under SDI followed by DI over the conventional aerobic rice. Present yield response of rice in drip irrigation was due to better water and nutrients discharge (1.0 lph DRE followed by $0.6 \mathrm{lph}$ DRE) to the root zone. These were in line with the recent work on drip-irrigated rice (Parthasarathi et al., 2018) along with plastic mulching (He et al., 2013). Higher harvest index of rice was due to the better balance between the source and sink under drip irrigation. This might be reasoned for the methane reduction (Denier et al., 2002) under drip environment.

The impact of methane emission calculated by the $\mathrm{CO}_{2}$-eq emission for the 100-year horizon was observed for each method. The SDI and DI treatments reduced the $\mathrm{CO}_{2}$-eq emission by $43.8 \%$ and $25.1 \%$ over conventional flood aerobic irrigation (Table 3). This reduction found a better result than the recent report (Oo et al., 2018a) on the alternate wetting and drying method (19\%-39\% better than the conventional flooded method). The decrease in methane emissions by SDI and DI was due to effective depression in $\mathrm{CO}_{2}$-eq methane emission. Yield-scaled $\mathrm{CO}_{2}$-eq emission provides a measure of agronomic efficiency to mitigate climate change and future food production concerns (Grassini \& Cassman, 2012). The yield-scaled $\mathrm{CO}_{2}$-eq emissions were higher $\left(594.2 \mathrm{~kg} \mathrm{CO}_{2}\right.$-eq t$\left.{ }^{-1}\right)$ using the conventional method than SDI +1.0 lph DRE practices (300.1 kg CO- eq $\mathrm{t}^{-1}$ ) due to their respective levels of methane emission rate. Therefore, the SDI $+1.0 \mathrm{lph}$ DRE practice is recommended for efficient reduction in $\mathrm{CO}_{2}$-eq methane emission along with increased grain yield and water productivity, rather than the conventional flood aerobic irrigation.

\section{Conclusion}

The present study demonstrated that drip irrigation practice can mitigate methane emissions and improved the growth and 
yield of rice when compared to conventional aerobic methods. The drip combinations SDI + 1.0 lph DRE, SDI + $0.6 \mathrm{lph}$ DRE, DI + 1.0 lph DRE and DI + 0.6 lph DRE could reduce the cumulative methane emission in aerobic rice by diminishing the flux rate. So far, it has been impossible to control the soil redox condition of conventional aerobic irrigated rice soil, but the drip irrigation practice (SDI or DI with 1.0 or 0.6 lph DRE) may offer the solution. The better performance of drip irrigation (i.e. SDI+ $1.0 \mathrm{lph}$ DRE) under aerobic conditions was also evident from their higher TDMA, root oxidase activity, soil methanotrophs population along with higher methane mitigation in comparison to the conventional. The SDI + 1.0 lph DRE practice can be applied in areas with inadequate water availability (i.e. where there are water shortages) for flooded rice production and the same practice is effective in reducing the $\mathrm{CO}_{2}$-eq emission and better grain yield than the conventional flood aerobic irrigation. In the case of climate change, drip irrigation systems have promise to ensure food security, while preserving irrigation water and mitigating methane gas emissions in rice. Further studies are required to test the methane-mitigating oxygen-nanobubble water (Minamikawa et al., 2015) under rice crop drip-irrigation, and to evaluate its mitigation potential regarding methane and other greenhouse gases.

\section{Data availability}

Underlying data

Open Science Framework: Methane Emission. https://doi. org/10.17605/OSF.IO/ZDY6U (Parthasarathi, 2019).
This project contains the following underlying data:

- Raw data methane emission (data concerning methane emission for each experimental group)

- Raw data weather (data concerning the weather for each experimental group)

\section{Extended data}

Open Science Framework: Methane Emission. https://doi. org/10.17605/OSF.IO/ZDY6U (Parthasarathi, 2019)

This project contains the following extended data:

- Supplementary Information (1) (containing Supplementary Figures 1 and 2)

- Supplementary Information (2) (containing supplementary Figure 3 and Supplementary Table 1)

Data are available under the terms of the Creative Commons Attribution 4.0 International license (CC-BY 4.0).

\section{Acknowledgements}

Authors should like to thank Dr. V.P. Dinesh Kumar for providing comments on early versions and language editing of the manuscript.
Adekoya MA, Liu Z, Vered E, et al:: Agronomic and Ecologicl Evaluation on Growing Water-Saving and Drought-Resistant Rice (Oryza sativa L.) Through Drip Irrigation. J of Agric Sci. 2014; 6(5): 110-119.

Publisher Full Text

Arafa R, AbdEl-Ghany AM, Sidkey FB, et al.: The Beneficial Use of Biofertilizers on Growth and yield of Wheat Plants Grown on Sandy Soil with or Without Nitrogen fertilization. Egyptian J Biotech. 2009; 32: 127-146.

Reference Source

Bhattacharyya P, Dash PK, Swain CK, et al.: Mechanism of plant mediated methane emission in tropical lowland rice. Sci Total Environ. 2019; 651(Pt 1): 84-92.

PubMed Abstract | Publisher Full Text

Bouman $\mathrm{B}$, Lampayan $\mathrm{R}$, Tuong $\mathrm{T}$ : Water management in irrigated rice: coping with water scarcity. Int Rice Res Inst. 2007; 54

Reference Source

Bouman BAM, Peng S, Castañeda AR, et al.: Yield and water use of irrigated tropical aerobic rice systems. Agric Water Manage. 2005; 74(2): 87-105. Publisher Full Text

Bouman BAM, Xiaoguang $\mathrm{Y}$, Huaqi W, et al:: Performance of aerobic rice varieties under irrigated conditions in North China. Field Crops Res. 2006; 97(1): 53-65.

Publisher Full Text

Bridgit AJ, Potty NN: Influence of root characters on rice productivity in iron soils of Kerala. Int Rice Res News. 2002; 27(1): 45-46.

Reference Source

Bronson K, Neue HU, Abao E, et al.: Automated chamber measurements of methane and nitrous oxide flux in a flooded rice soil: II. Fallow period emissions. Soil Sci Soc Am J. 1997; 61(3): 988-993.

Publisher Full Text

Dass A, Chandra S, Choudhary AK, et al:: Influence of field re-ponding pattern and plant spacing on rice root-shoot characteristics, yield, and water productivity of two modern cultivars under SRI management in Indian Mollisols. Paddy Water Environ. 2016; 14(1): 45-59.

Publisher Full Text
Dastane NG: Effective rainfall in irrigated agriculture, Food and Agriculture Organization of the United Nations, Rome, Italy.1974; 62. Reference Source

Denier Van Der Gon HA, Kropff MJ, Van Breemen N, et al:: Optimizing grain yields reduces $\mathrm{CH}_{4}$ emissions from rice paddy fields. Proc National Acad Sci. 2002; 99(19): 12021-24.

PubMed Abstract | Publisher Full Text | Free Full Text

Dorau K, Mansfeldt T: Manganese-oxide-coated redox bars as an indicator of reducing conditions in soils. J Environ Qual. 2015; 44(2): 696-703.

PubMed Abstract | Publisher Full Text

Feng J, Chen C, Zhang Y, et al:: Impacts of cropping practices on yield-scaled greenhouse gas emissions from rice fields in China: a meta-analysis. Agric Ecosyst Environ. 2013; 164: 220-228.

Publisher Full Text

Geethalakshmi V, Ramesh T, Palamuthirsolai A, et al:: Agronomic evaluation of rice cultivation systems for water and grain productivity. Arch Agron Soil Sci. 2011; 57(2): 159-166.

Publisher Full Text

Gomez KA, Gomez AA: Statistical procedures for agricultural research, ( $2^{\text {nd }}$ Ed.). John Wiley and Sons, New York, USA 680. 1984

Reference Source

Graham DW, Korich DG, LeBlanc RP, et al:: Applications of a colorimetric plate assay for soluble methane monooxygenase activity. Appl Environ Microbiol. 1992; 58(7): 2231-36.

PubMed Abstract | Free Full Text

Grassini P, Cassman KG: High-yield maize with large net energy yield and small global warming intensity. Proc Nat Acad Sci USA. 2012; 109: 1074-79.

PubMed Abstract | Publisher Full Text | Free Full Text

Hanson RS, Hanson TE: Methanotrophic bacteria. Microbiol Rev. 1996; 60(2): 439-471.

PubMed Abstract | Free Full Text

$\mathrm{He} \mathrm{H,} \mathrm{Ma} \mathrm{F,} \mathrm{Yang} \mathrm{R,} \mathrm{et} \mathrm{al.:} \mathrm{Rice} \mathrm{performance} \mathrm{and} \mathrm{water} \mathrm{use} \mathrm{efficiency} \mathrm{under}$ plastic mulching with drip irrigation. PLOS One. 2013; 8(12): e83103. PubMed Abstract | Publisher Full Text | Free Full Text 
Hutchinson GL, Mosier AR: Improved soil cover method for field measurement of nitrous oxide fluxes. Soil Sci Soc Am J. 1981; 45(2): 311-316. Publisher Full Text

IPCC (Intergovernmental Panel on Climate Change): The physical science basis. In: Stocker TF, Qin D, Plattner GK, Tignor M, Allen SK, Boschung J, Nauels A, Xia Y, Bex V and Midgley PM (Eds) Contribution of Working Group I to the Fifth Assessment Report of the Intergovernmental Panel on Climate Change. Cambridge University Press, Cambridge, United Kingdom and New York, NY USA,1535. 2013. Reference Source

Jain N, Dubey R, Dubey DS, et al:: Mitigation of greenhouse gas emission with system of rice intensification in the Indo-Gangetic Plains. Paddy Water Environ. 2014; 12(3): 355-363.

Publisher Full Text

Jiao Z, Hou A, Shi Y, et al:: Water management influencing methane and nitrous oxide emissions from rice field in relation to soil redox and microbial community. Comm Soil Sci Plant Ana. 2006; 37(13): 1889-03.

Publisher Full Text

Joshi R, Mani SC, Shukla A, et al:: Aerobic rice: water use sustainability. OryzaAn Int $J$ on Rice. 2009; 46(1): 1-5.

Reference Source

Kajiura M, Minamikawa K, Tokida T, et al:: Methane and nitrous oxide emissions from paddy fields in Japan: An assessment of controlling factor using an intensive regional data set. Agric Ecosys Environ. 2018; 252: 51-60.

Publisher Full Text

Kato S, Hashimoto K, Watanabe K: Methanogenesis facilitated by electric syntrophy via (semi)conductive iron-oxide minerals. Environ Microbiol. 2012; 14(7): 1646-54.

PubMed Abstract | Publisher Full Text

Kato Y, Okami M, Katsura K, et al.: Yield potential and water use efficiency of aerobic rice (Oryza sativa. L) in Japan. Field Crops Res. 2009; 113(3): 328-334. Publisher Full Text

Keppler F, Hamilton JT, Braß M, et al.: Methane emissions from terrestrial plants under aerobic conditions. Nature. 2006; 439(7073): 187-191.

PubMed Abstract | Publisher Full Text

Kludze HK, DeLaune RD, Patrick WH: Aerenchyma formation and methane and oxygen exchange in rice. Soil Sci Soc Am J. 1993; 57(2): 386-391.

Publisher Full Text

Kong L, Wang YB, Zhao LN, et al:: Enzyme and root activities in surface-flow constructed wetlands. Chemos. 2009; 76(5): 601-608.

PubMed Abstract | Publisher Full Text

Kongchum M: Effect of plant residue and water management practices on soil redox chemistry, methane emission, and rice productivity. Ph.D. Thesis M.S.

Khon Kaen University, Thailand, 2005; 1-167.

Reference Source

Luo GJ, Kiese R, Wolf B, et al: Effects of soil temperature and moisture on methane uptake and nitrous oxide emissions across three different ecosystem types. Biogeosci. 2013; 10(5): 3205-19.

Publisher Full Text

Malyan SK, Bhatia A, Kumar A, et al:: Methane production, oxidation and mitigation: a mechanistic understanding and comprehensive evaluation of influencing factors. Sci Total Environ. 2016; 572: 874-896.

PubMed Abstract | Publisher Full Text

Ma KE, Qiu Q, Lu Y: Microbial mechanism for rice variety control on methane emission from rice field soil. Glob Change Biol. 2010; 16: 3085-3095.

Publisher Full Text

Minamikawa K, Tokida T, Sudo S, et al:: Guidelines for measuring $\mathrm{CH}_{4}$ and $\mathrm{N}_{2} \mathrm{O}$ emissions from rice paddies by a manually operated closed chamber method. National institute for agro-environmental science, Tsukuba, Japan, 2015. Reference Source

Oo AZ, Sudo S, Inubushi K, et al.: Methane and nitrous oxide emissions from conventional and modified rice cultivation systems in South India. Agric Ecosys Environ. 2018a; 252: 148-158.

Publisher Full Text

Oo AZ, Sudo S, Inubushi K, et al:: Mitigation Potential and Yield-Scaled Global Warming Potential of Early-Season Drainage from a Rice Paddy in Tamil Nadu, India. Agron. 2018b; 8(202): 1-17.

Publisher Full Text

Ota Y: Diagnostic method for measurement of root oxidase activity in rice plant. Jap Agric Res Q. 1970; 5: 1-6.

Reference Source

Parthasarathi T: Methane emission. 2019.

http://www.doi.org/10.17605/OSF.IO/ZDY6U

Parthasarathi T, Mohandass S, Senthilvel S, et al:: Effect of various micro irrigation treatments on growth and yield response of aerobic rice. Int Agric Eng J. 2013; 22: 49-62.

Reference Source

Parthasarathi T, Vanitha K, Mohandass S, et al.: Evaluation of Drip Irrigation System for Water Productivity and Yield of Rice. Agron J. 2018; 110(6): 1-12. Publisher Full Text

Parthasarathi T, Vanitha K, Mohandass S, et al:: Effects of impulse drip irrigation systems on physiology of aerobic rice. Indian J Plant Physiol. 2015; 20(1): $50-56$.

Publisher Full Text
Parthasarathi T, Vanitha K, Mohandass S, et al:: Variation in rice root traits assessed by phenotyping under drip irrigation [version 2; peer review: 1 approved, 2 not approved]. F1000 Res. 2017; 6: 125.

Publisher Full Text

Peng S, Bouman B, Visperas RM, et al:: Comparison between aerobic and flooded rice in the tropics: Agronomic performance in an eight season experiment. Field Crops Res. 2006; 96(2-3): 252-259.

Publisher Full Text

Rajkishore SK, Doraisamy P, Subramanian KS, et al.: Methane emission patterns and their associated soil microflora with SRI and conventional systems of rice cultivation in Tamil Nadu, India. Taiwan Water Conser. 2013; 61(4): 126-134.

Rajwade YA, Swain DK, Tiwari KN, et al.: Grain yield, water productivity, and soil nitrogen dynamics in drip irrigated rice under varying nitrogen rates. Agron $J$. 2018; 110(3): 868-878.

Publisher Full Text

Reis AFB, Almeida REM, Lago BC, et al:: Aerobic rice system improves water productivity, nitrogen recovery and crop performance in Brazilian weathered lowland soil. Field Crops Res. 2018; 218: 59-68.

Publisher Full Text

Sander BO, Wassmann R, Siopongco JD: Mitigating greenhouse gas emissions from rice production through water-saving techniques: potential, adoption and empirical evidence. In: Hoanh C, Smakhtin V and Johnston R (Eds.), Climate Change and Agricultural Water Management in Developing Countries, CAB International, Oxfordshire, UK. 2015; 193-207.

Sandin S: Present and future methane emissions from rice fields in Đông Ngac commune, Hanoi, Vietnam. Göteborg University, Department of Physical Geography. 2005; 41

Reference Source

Setyanto $\mathrm{P}$, Pramono A, Adriany TA, et al: Alternate wetting and drying reduces methane emission from a rice paddy in Central Java, Indonesia without yield loss. Soil Sci Plant Nut. 2018; 64(1): 23-30.

Publisher Full Text

Sharkawi HME, Sherif A, Zahoor A, et al:: Methane emission and its relations with plant parameters and dissolved oxygen in different rice genotypes. $J$ Food Agric Environ. 2009; 7(2): 463-470.

Sharma SK, Singh YV, Tyagi S, et al:: Influence of rice varieties, nitrogen management and planting methods on methane emission and wate productivity. Paddy Water Environ. 2016; 14(2): 325-333.

Publisher Full Text

Smith $\mathrm{P}$, Martino D, Cai Z, et al.: Greenhouse gas mitigation in agriculture. Philos Trans R Soc Lond B Biol Sci. 2008; 363(1492): 789-813.

PubMed Abstract | Publisher Full Text | Free Full Text

Sun $\mathrm{H}$, Zhou S, Fu Z, et al.: A two-year field measurement of methane and nitrous oxide fluxes from rice paddies under contrasting climate conditions. Sci Rep. 2016; 6: 28255.

PubMed Abstract | Publisher Full Text | Free Full Text

Sun $\mathrm{H}$, Zhou S, Fu Z, et al.: A two-year field measurement of methane and nitrous oxide fluxes from rice paddies under contrasting climate conditions. Sci Rep. 2016; 6: 28255.

PubMed Abstract | Publisher Full Text | Free Full Text

Suryavanshi P, Singh YV, Prasanna R, et al:: Pattern of methane emission and water productivity under different methods of rice crop establishment. Paddy Water Environ. 2013; 11(1-4): 321-329.

Publisher Full Text

TNAU Crop Production Guide: Production technology of rice. 2014

Reference Source

Trost B, Prochnow A, Drastig K, et al.: Irrigation, soil organic carbon and $\mathrm{N}_{2} \mathrm{O}$ emissions. A review Agron Sustain Dev. 2013; 33(4): 733-749.

Publisher Full Text

Tubiello FN, Salvatore M, Rossi S, et al:: The Faostat database of greenhouse gas emissions from agriculture. Environ Res Lett. 2013; 8(1): 015009.

Publisher Full Text

Tuong TP, Bouman BAM: Rice production in water-scarce environments. In: Proceedings of the Water Productivity Workshop. International Water Management Institute, Colombo, Sri Lanka. 2003.

Reference Source

Yan $\mathrm{XY}$, Yagi $\mathrm{K}$, Akiyama $\mathrm{H}$, et al.: Statistical analysis of the major variables controlling methane emission from rice fields. Glob Change Biol. 2005; 11(7): $1131-41$.

Publisher Full Text

Yang J, Zhang J: Crop management techniques to enhance harvest index in rice. J Exp Bot. 2010; 61(12): 3177-89.

PubMed Abstract | Publisher Full Text

Yang $\mathrm{ZH}$, Huang $\mathrm{H}$, Wang $\mathrm{H}$ : Paddy soil quality of a wetland rice-duck complex ecosystem. Chinese J Soil Sci. 2005; 35(2): 117-121.

Yoshida S, Foron DA, Cock JH: Laboratory manual for physiological studies of rice. International Rice Research Institute, Los Baños, Philippines, 1971; 70.

Zhao B, Zhang J, Lv X, et al:: Methane oxidation enhancement of rice roots with stimulus to its shoots. Plant Soil Environ. 2013; 59(4): 143-149.

Publisher Full Text

Zhou S, Xu J, Yang G, et al:: Methanogenesis affected by the co-occurrence of iron(III) oxides and humic substances. FEMS Microbiol Ecol. 2014; 88(1): 107-120. PubMed Abstract | Publisher Full Text 


\section{Open Peer Review}

\section{Current Peer Review Status:}

\section{Version 1}

Reviewer Report 09 July 2021

https://doi.org/10.5256/f1000research.23049.r87960

(C) 2021 Arbat G. This is an open access peer review report distributed under the terms of the Creative Commons Attribution License, which permits unrestricted use, distribution, and reproduction in any medium, provided the original work is properly cited.

\section{Gerard Arbat}

Department of Chemical and Agricultural Engineering and Technology, University of Girona, Girona, Catalonia, 17003, Spain

The paper deals with methane emission, water use, and water productivity of drip irrigated rice compared with conventional flooded aerobic irrigation. The study includes surface and subsurface drip irrigation with two different flowrates. The main results of the paper are that drip irrigation reduces methane emissions and increases water productivity. The best option for this irrigation system is subsurface drip irrigation at a flowrate of $1 \mathrm{lph}$.

My recommendation would be a "Minor revision". This revision may include the following changes:

1. Include the soil texture (\%sand, silt and clay) in table 1, as it can affect the results obtained

2. Define 'standard weeks' in Fig. 1.

3. Show in Fig. 2 the exact location of the chamber, as it is described in Methane sampling and analysis section: "...placed in between the laterals and $15 \mathrm{~cm}$ from the emitters."

4. In the section soil characteristics, the measurements are not only related to physical characteristics, please them describe accordingly.

5. In the section plant characteristics, define what a hill is.

6. In Fig.3, the vertical titles of figs. B and $E$ are in different location than the other figures. Please be consistent.

Is the work clearly and accurately presented and does it cite the current literature? Yes

Is the study design appropriate and is the work technically sound? 
Are sufficient details of methods and analysis provided to allow replication by others? Yes

If applicable, is the statistical analysis and its interpretation appropriate? Yes

Are all the source data underlying the results available to ensure full reproducibility? Yes

Are the conclusions drawn adequately supported by the results? Yes

Competing Interests: No competing interests were disclosed.

Reviewer Expertise: Irrigation Engineer

I confirm that I have read this submission and believe that I have an appropriate level of expertise to confirm that it is of an acceptable scientific standard.

Reviewer Report 03 January 2020

https://doi.org/10.5256/f1000research.23049.r57226

(C) 2020 Hanjagi P. This is an open access peer review report distributed under the terms of the Creative Commons Attribution License, which permits unrestricted use, distribution, and reproduction in any medium, provided the original work is properly cited.

\section{Prashantkumar S. Hanjagi}

Division of Plant Physiology, ICAR-Indian Agricultural Research Institute, New Delhi, Delhi, India

Thanks for asking me to review this article. The authors of the study have generated very good data to communicate the key message on mitigation of methane emission in rice by different irrigation methods. My recommendation would be in and around "Minor revision".

My minor comments to the authors are:

1. In the Introduction text, the previously reported value for reduction in methane emissions due to alternate wetting and drying is $44.0 \%$. But, in abstract it is being mentioned as $47.5 \%$. Right value may be mentioned here.

2. In methods section, treatments can be mentioned in a tabular form for better understanding of readers instead of writing in running text.

3. For figure 2, Authors could have presented the real set-up of closed diffusion chambers used to collect methane emission in the present study instead of diagrammatic representation.

4. Rewrite this sentence "This response was further confirmed an increased in methanotroph 
population of ..." in results section (page no 7).

Is the work clearly and accurately presented and does it cite the current literature? Yes

Is the study design appropriate and is the work technically sound?

Yes

Are sufficient details of methods and analysis provided to allow replication by others? Yes

If applicable, is the statistical analysis and its interpretation appropriate?

Yes

Are all the source data underlying the results available to ensure full reproducibility? Yes

Are the conclusions drawn adequately supported by the results?

Yes

Competing Interests: No competing interests were disclosed.

Reviewer Expertise: My research program is multidisciplinary in nature, combining physiology, molecular biology, and proteomics. Currently my research focuses on understanding the cellular and molecular mechanisms mediating the response(s) of plants to abiotic stress (Salt, drought, heat, lodging, etc). I have expertise in automated high-throughput plant phenotyping in getting insights into genomic performance and plant-environment-interactions through non-destructive analysis of phenotypic traits of the major crops like maize, rice, wheat, and pulses. Within my group, during past years, we have attempted to characterize the role of candidate genes (NHX1 \& AVP1) in improving tolerance to salt stress tolerance in rice.

I confirm that I have read this submission and believe that I have an appropriate level of expertise to confirm that it is of an acceptable scientific standard. 
The benefits of publishing with F1000Research:

- Your article is published within days, with no editorial bias

- You can publish traditional articles, null/negative results, case reports, data notes and more

- The peer review process is transparent and collaborative

- Your article is indexed in PubMed after passing peer review

- Dedicated customer support at every stage

For pre-submission enquiries, contact research@f1000.com 